\title{
Penggunaan Media Pembelajaran Flashcard untuk Meningkatkan Penguasaan Vocabulary dengan Materi Narrrative Text
}

\author{
Latifah Fidiyanti ${ }^{*}$ \\ Sekolah Menengah Kejuruan Negeri 1 Dlanggu
}

\section{A R T I C L E I N F O}

Article history:

Received 12 December 2019

Received in revised form

01 January 2020

Accepted 30 January 2020

Available online 27

February 2020

Kata Kunci:

Media Flashcard,

Kemampuan Siswa,

Kosakata, BahasaInggris.

Keywords:

Flashcard Media, Student

Ability, Vocabulary,

English.

\begin{abstract}
A B S T R A K
Tujuan melaksanakan penelitian ini adalah Untuk mengetahui proses pembelajaran dan peningkatan kemampuan kosa kata siswa dalam pembelajaran Bahasa Inggris. Dengan menggunakan media flashcard di Kelas XI RPL2 SMK N 1 DLANGGU. Metode penilitian yang digunakan adalah penelitian tindakan kelas (PTK) dengan tahap-tahap sebagai berikut: perencanaan (planning), pelaksanaan tindakan (acting), pengamatan(observing) dan refleksi (reflecting). Teknik pengumpulan data yang digunakan dalam penelitian ini adalah: (1) tes, (2) wawancara, (3) observasi. Hasil yang didapat dari penelitian ini adalah untuk pelaksanaan tindakan pertama pembelajaran belum mencapai hasil yang maksimal,hal ini dapat dilihat masih adanya siswa yang kurang melibatkan diri dalam penggunaan media flashcard dan masih adanya siswa merasa bingung dengan apa yang diintruksikan guru sehingga nilai rata-rata yang didapat siswa pada siklus I adalah 68, dengan ketuntasan belajar sekitar $72 \%$. Dengan melihat Kriteria Ketuntasan Minimum (KKM) yang telah ditentukan di SMKN 1 DLANGGU yaitu 65, ada 13 Orang yang mencapai kriteria tuntas, artinya hanya $72 \%$ sedangkan menurut KTSP suatu pembelajaran dikatakan tuntas apabila nilai ketuntasan yang didapat siswa $\geq 75 \%$ dari jumlah siswa. Adapun pada siklus II mengalami peningkatan dengan nilai rata-rata yang didapat siswa pada siklus II adalah 84 , dengan ketuntasan belajar sekitar $100 \%$.
\end{abstract}

\section{A B S T R A C T}

The purpose of conducting this research was to find out the learning process and improvement of students' vocabulary skills in learning English by using flashcard media at XI Grade students of RPL2 SMK N 1 DLANGGU. The research method was classroom action research (CAR) with the following stages: planning, implementing actions (acting), observing and reflecting. Data collected by: (1) tests, (2) interviews, (3) observations. The results from this study for the first implementation was not reached maximum results, it can be seen that there are still students who are less involved in the use of flashcard media and there are still students who feel confused by what instructed by the teacher so that the average value obtained by students in the first cycle is 68, with mastery learning around $72 \%$. By looking at the Minimum Completion Criteria (KKM) that have been determined in the SMK 1 DLANGGU that is 65, there are 13 people who reach the completion criteria, meaning only $72 \%$ whereas according to KTSP a learning is said to be complete if the completeness value obtained by students $\geq 75 \%$ of the number of students. The second cycle increased with the average value obtained by students in the second cycle was 84 , with a learning completeness of about $100 \%$. 


\section{Pendahuluan}

Pendidikan Bahasa mempunyai peran yang sangat penting dalam era globalisasi, terlebih fungsi bahasa sebagai alat komunikasi, salah satu bahasa yang harus dikuasai adalah Bahasa Inggris, karena Bahasa Inggris merupakan bahasa internasional dan dijadikan sebagai alat untuk berkomunikasi baik lisan maupun tulisan. Berkomunikasi adalah memahami dan mengungkapkan informasi, pikiran, perasaan, dan mengembangkan ilmu pengetahuan, teknologi, dan budaya. Kemampuan berkomunikasi dalam pengertian yang utuh adalah kemampuan berwacana, yakni kemampuan memahami dan menghasilkan teks lisan atau tulis yang direalisasikan dalam empat keterampilan berbahasa, yaitu mendengarkan, berbicara, membaca dan menulis. Keempat keterampilan inilah yang digunakan untuk menanggapi atau menciptakan wacana dalam kehidupan bermasyarakat.

Mata pelajaran Bahasa Inggris diarahkan untuk mengembangkan keterampilan- keterampilan tersebut agar lulusan mampu berkomunikasi dan berwacana dalam Bahasa Inggris pada tingkat literasi tertentu Guru dalam proses pembelajaran belum menyentuh ranah siswa sehingga belum menumbuhkan rasa aktif, inovatif, kreatif, dan menyenangkan. Keadaan ini diperparah lagi oleh pembelajar yang berorientasi pada ujian sehingga mengakibatkan proses, sikap, dan aplikasi tidak tersentuh dalam pembelajaran. Pengalaman belajar di kelas tidak utuh dan tidak beroreantasi pada tercapainya standar kompetensi dan kompetensi dasar. Pembelajaran lebih berpusat pada guru (teacher-centered).Belajar laksana menuangkan air di dalam gelas yang kosong, artinya "menjejalkan" pengetahuan kepada siswa, air sama dengan pengetahuan, sedangkan gelas sama dengan siswa. Pelaksanaan pembelajaran yang dilaksakan oleh guru menggunakan model 4D (datang, duduk, dengar, dan diam) ditambah lagi catat dan hafal.

Bahasa Inggris di Sekolah Menengah Kejuruan merupakan pelajaran yang wajib bagi semua siswa pada tingkat Sekolah Menengah Kejuruan. Bahasa Inggris pada tingkat Sekolah Menengah Kejuruan bertujuan agar peserta didik dapat mengembangkan kompetensi berkomunikasi dan memiliki kesadaran tentang hakikat dan pentingnya Bahasa Inggris untuk meningkatkan daya saing bangsa dalam masyarakat global. Untuk mencapai tujuan tersebut dituntut kemampuan dasar berkomunikasi, salah satunya kemampuan yang harus dimiliki berupa penguasaan kosakata. Untuk memperoleh kemampuan tersebut maka pembelajaran harus dilakukan secara interaktif, inspiratif, menyenangkan, ditunjang dengan penggunaan media yang dapat memotivasi pesertadidik untuk berpartisipasi aktif dalam pembelajaran..

Guru menggunakan pembelajaran yang bersifat konvensional, dimana yang berperan aktif bukan lagi siswa melainkan guru.Dalam proses pembelajaran ini, siswa dibebani hafalan-hafalan yang sangat banyak sehingga siswa belum termotivasi. Proses pembelajaran yang selama ini dilakukan oleh guru adalah: (1) Guru tidak aktif (pasif) dalam proses pembelajaran, menyampaikan materi hanya menggunakan satu pendekatan, yaitu ceramah saja mulai dari masuk sampai berakhir proses pembelajaran, sehingga siswa hanya mendengar informasi yang diberikan guru. Hal ini mengakibatkan siswa malas dan tidak bersemangat; (2) Guru tidak inovatif dalam proses pembelajaran. Guru tidak mengembangkan gaya dan perangkat pembelajaran, serta tidak memberi pembaharuan dalam proses pembelajaran sehingga siswa tidak menyenangi pelajaran karena tidak mendapatkan sesuatu hal yang baru dan menantang;(3)Guru tidak kreatif, maksudnya guru dalam proses pembelajarannya tidak mempersiapkan perangkat pembelajaran seperti tidak menggunakan media pembelajaran yang sesuai dengan materi yang diajarkan; (4) Guru kaku, menegangkan,marah-marah yang membuat siswa merasa takut kepada guru dan membuat siswa malas dan tidak mau masuk untuk mengikuti proses pembelajaran.

Siswa tidak dibiasakan untuk mengembangkan potensi berpikirnya. Fakta dilapangan menunjukkan bahwa banyak siswa yang cenderung menjadi malas berpikir secara mandiri, cara berpikir yang dikembangkan dalam kegiatan belajar belum menyentuh domain afektif dan psikomotor. Memang pembelajaran yang berorientasi target penguasaan materi terbukti berhasil dalam kompetensi mengingat dalam jangka pendek, tetapi gagal dalam membekali anak memecahkan masalah dalam kehidupan jangka panjang.

Pendidikan adalah proses untuk menghasilkan lulusan yang kompeten dan cerdas, sehingga dapat melanjutkan pendidikan ke jenjang yang lebih tinggi. Hal ini hanya dapat tercapai apabila proses pembelajaran yang berlangsung mampu mengembangkan seluruh potensi yang dimiliki siswa, dan siswa terlibat langsung dalam pembelajaran. Untuk itu, guru perlu meningkatkan mutu pembelajarannya, dimulai dengan rancangan pembelajaran yang baik dengan memperhatikan tujuan, karakteristik siswa,materi yang diajarkan, dan sumber belajar yang tersedia. Namun pada kenyataannya masih banyak ditemui proses pembelajaran yang kurang berkualitas, tidak efisien dan kurang mempunyai daya tarik, bahkan cenderung membosankan, sehingga hasil belajar yang dicapai tidak optimal.

Rendahnya perolehan hasil belajar mata pelajaran bahasa Inggrismerupakan salah satu indikasi dari rendahnya prestasi belajar siswa dan kemampuan guru dalam mengelola pembelajaran yang 
berkualitas. Untuk mengetahui mengapa prestasi siswa tidak sesuai dengan yang diharapkan, guru perlu merefleksi diri untuk dapat mengetahui faktor-faktor penyebab ketidakberhasilan siswa dalam pelajaran bahasa Inggris.

Untuk mengatasi atau mengurangi kelemahan-kelemahan yang ada dalam penerapan pembelajaran pada mata pelajaran bahasa Inggris, maka perlu didukung oleh penggunaan alat bantu atau media pembelajaran. Suatu media hanya dapat dikatakan memiliki keunggulan dibanding media pembelajaran lainnya bila ia digunakan oleh pebelajar yang memiliki karakteristik (termasuk gaya belajar) sesuai dengan rangsangan yang ditimbulkan oleh media pembelajaran tersebut (Degeng, 2010:12). Dengan demikian, media pembelajaran media interaktif audio visual dapat membuat proses pembelajaran menjadi proses yang aktif, dan pebelajar lebih termotivasi untuk belajar menurut minat dan kemampuannya (Sadiman, et al., 2011:17). Sedangkan media pembelajaran yang sesuai dengan karakteristik pembelajar merupakan salah satu faktor yang mampu menghadirkan rangsanganrangsangan yang menjadikan peristiwa pembelajaran semakin berkualitas (Gagne et al., 2011).

Menurut Gerlach \& Ely (2012:240), pemilihan dan penggunaan media pembelajaran yang tepat mampu menciptakan kondisi dimana pebelajar mampu melakukan tindakan tertentu yang menjadi tujuan pembelajaran. Media pembelajaran yang tepat, mampu memotivasi belajar, memudahkan belajar, merangsang berpikir, dan menciptakan suasana yang sedikit kurang formal.

Media Pembelajaran menurut Hadimiarso (2007:458) adalah segala sesuatu yang digunakan untuk menyalurkan pesan serta dapat merangsang pikiran, perasaan, perhatian dan kemauan si belajar sehingga dapat mendorong terjadinya proses belajar yang disengaja, bertujuan dan terkendali. Hamalik (Arsyad, 2006:15) mengemukakan bahwa pemakaian media pembelajaran dalam proses belajar mengajar dapat membangkitkan keinginan dan minat yang baru, membangkitkan motivasi dan rangsangan kegiatan belajar bahkan membawa pengaruh-pengaruh psikologis terhadap anak. Dari beberapa pendapat para ahli di atas dapat disimpulkan bahwa, ketepatan menentukan dan menggunakan media dalam proses pembelajaran sangat penting guna meningkatkan efektivitas dan efisiensi belajar sehingga tujuan dari proses pembelajaran dapat tercapai.

Menurut Sudjana (2005:2) penggunaan media pembelajaran dapat mempertinggi proses belajar siswa, sebab: a) Pengajaran akan menarik perhatian siswa sehingga dapat menumbuhkan motivasi belajar, b) bahan pengajaran akan lebih jelas maknanya sehingga dapat lebih dipahami oleh siswa dan memungkinkan siswa menguasai tujuan pengajaran lebih baik, c) Metode mengajar akan lebih bervariasi, tidak semata-mata komunikasi verbal melalui penuturan kata-kata oleh guru sehingga siswa tidak bosan dan guru tidak kehabisan tenaga, apalagi guru mengajar untuk setiap jam pelajaran, d) siswa lebih banyak melakukan kegiatan belajar, sebab tidak hanya mendengarkan uraian guru, tetapi juga aktivitas lain seperti mengamati, melakukan, mendemonstrasikan,dan lain-lain (Kusumawati, 2016).

Media flashcard merupakan media kartu yang berisi gambar, tulisan yang dapat dibuat sebagai permainan kartu sehingga sangat memungkinkan siswa tertarik untuk memehami materi yang disampaikan. Masa anak-anak identik dengan masa bermain. Maka pembelajaran untuk anak kelas III yang masih dalam tahap pertumbuhan, pembelajaran akan lebih optimal jika mengandung unsur permainan. Dengan adanya media flashcard siswa dapat belajar sambil bermain. Sehingga minat siswa untuk belajar akan lebih besar dan pembelajaran akan lebih menyenangkan. Setiap kartu akan diacak tanpa siswa mengetahui apa yang ada di balik kartu-kartu yang mereka ambil secara acak. Kartu dapat berisi soal-soal ataupun berisi gambar yang dilengkapi dengan soal. Permainan kartu yang demikian akan membuat siswa lebih giat dalam belajar sebagai persiapan menghadapi apa yang dapat mereka temukan pada kartu yang telah dipilihnya serta siswa akan lebih termotivasi dengan adanya persaingan antar siswa atau kelompok. Dengan menggunakan media flashcard pada pembelajaran tematik kelas III di SDN Denanyar II Jombang diharapkan dapat memberikan pengalaman bermakna kepada siswa serta mempermudah memahami materi yang disampaikan oleh guru. Penggunaan media flashcard juga diharapkan dapat membantu guru memotivasi siswa sehingga hasil belajar siswa dapat meningkat (Maghfiroh, 2013).

Bloom (2011:169) berpendapat bahwa faktor karakteristik pebelajar, kualitas pembelajaran, dan proses pembelajaran, memiliki relevansi yang kuat dengan perolehan hasil belajar. Pendapat tersebut didasarkan pada berbagai hasil penelitian sehingga dapat diketahui adanya interaksi antara penggunaan media pembelajaran dalam memperoleh hasil belajar.

Sejalan dengan pendapat tersebut, Degeng (2012:12) menyatakan bahwa kehadiran media pembelajaran perlu memperhatikan gaya belajar pebelajar. Dengan demikian, kehadiran media pembelajaran yang tepat akan dapat membuat kualitas pembelajaran semakin berbobot.

Tujuan akhir pembelajaran bahasa Inggris adalah kemampuan siswa menguasai aspek-aspek kebahasaan, seperti: aspek bunyi (phonology), aspek tata bahasa (grammar), aspek kosa kata 
(vocabulary), dan diaplikasikan ke dalam empat keterampilan berbahasa, yaitu: menyimak (listening), berbicara (speaking), membaca (reading), dan menulis (writing).

Semua kemampuan ini disebut kemampuan berbahasa (proficiency). Untuk meningkatkan kemampuan siswa dalam berbahasa Inggris, ada tiga aspek kebahasaan yang harus dikuasai siswa, yaitu: aspek bunyi bahasa dan sistem penulisan (pronunciation/orthography), aspek tata bahasa (grammar and structure), dan aspek kosakata (vocabulary). Ketiga aspek ini terakomodasi pada empat keterampilan berbahasa (language skills), yaitu: keterampilan menyimak (listening skills), keterampilan berbicara (speaking skill), keterampilan membaca (reading skill), dan keterampilan menulis (writing skill).

Berdasarkan latar belakang masalah tersebut diatas, maka penelitiingin melakukan penelitian dengan judul "Penggunaan Media Pembelajaran Flash Card Untuk Meningkatkan Penguasaan Vocabulary dengan Materi Narrative teks Siswa Kelas XIRPL2 SMKN I Dlanggu Kabupaten Mojokerto Tahun Ajaran 2019-2020.

\section{Metode}

Kegiatan yang dilakukan oleh peneliti pada tahap perencanaan adalah:

a. Peneliti melakukan analisis kurikulum untuk menentukan standar kompetensi dan kompetensi dasar yang disampaikan kepada siswa dengan menggunakan pembelajaran dengan media flash card

b. Membuat RPP siklus I dengan model pembelajaran dengan media pebelajaran flaash card .Membuat lembar observasi siklus I untuk melihat bagaimana kondisi belajar mengajar dikelas ketika latihan dan kerja kelompok dilaksanakan.

c. Membuat Lembar Kerja Siswa siklus I

d. Membentuk kelompok yang bersifat heterogen baik dari segi kemampuan akademis, jenis pembelajaran dengan menggunakan media pembelajaran flash card pada siklus I

e. Menyusun alat evaluasi pembelajaran berdasarkan perkembangan untuk dilaksanakan pada siklus II serta menyiapkan instrumen pendukung pembelajaran lainnya.

Selama pembelajaran langsung dilakukan observsi untuk mengetahui penggunaan media pembelajaran flash carddalam meningkatkan penguasaan vocabulary pada proses pembelajaran Bahasa Inggris. Langkah selanjutnya bagi peneliti adalah pelaksanaan. Pada tahap ini perencanaan yang sudah dibuat peneliti akan dilaksanakan dalam kegiatan pembelajaran. Tahap pengamatan atau observasi dilakukan bersamaan dengan pelaksanaan tindakan. Pada tahap ini peneliti di bantu oleh guru atau teman sejawat untuk mencatat semua hal yang diperlukan dalam penelitian berupa pengumpulan data-data.

Ketika dilaksanakan kegiatan vocabulary kebanyakan siswa yang tidak tahu dan tidak paham, sehingga tidak bisa menjawab pertanyaan yang berkenaan dengan soal vocabulary Karena ketidakpahaman dan ketidakmapuan daam menjawab soal-soal listening, suasana kelas tampak gaduh dan sulit dikendalikan.

\section{Hasil dan Pembahasan}

Data hasil pretes kelompok siswa yang mendapat perlakuan metode pembelajaran ekspositori dengan, dianalisis dengan teknik statistik uji-t dua sampel independen. Tujuan analisis statistik ini adalah untuk mengetahui tingkat kesetaraan kelompok siswa tersebut.

Tabel 1. Pre Test Rata-rata Nilai Kemampuan Reading

\begin{tabular}{lll}
\hline No. & Penguasaan Vocabulary Materi & Rata-rata \\
& & Nilai \\
\hline 1 & Reading & 69,00 \\
2 & Grammar & 69,85 \\
Rata-rata nilai & 69,425 \\
\hline
\end{tabular}

Berdasarkan isi Tabel 1 terlihat bahwa nilai pretes kelompok siswa sebelum mendapat perlakuan pembelajaran dengan media flash card adalah 69,425.

\section{A. Perencanaan Tindakan Siklus 1}

Perencanaan di mulai dengan membentuk kelompok diskusi. Siswa yang berjumlah 32 siswa dibagi menjadi 4 kelompok sehingga masing-masing kelompok berjumlah 8 siswa. Materi pelajaran yang diajarkan pada siklus I ini adalah pokok bahasan Narrative teks. Proses pembelajaran pokok bahasan 
Narrative teks ini menggunakan media interaktif yang diterapkan oleh guru secara langsung dalam pembelajaran di kelas.

B. Pelaksanaan Tindakan Siklus 1

Pelaksanaan tindakan siklus I dapat diuraikan sebagai berikut:

a. Guru mengawali pembelajaran dengan mengucapkan salam dan menanyakan jumlah siswa yang hadir.

b. Guru melaksanakan apersepsi.

c. Guru membagi siswa dalam kelompok diskusi, kemudian memberi tugas yang berkaitan dengan penggunaan media pembelajaran flash card

d. Guru memberi tugas kepada siswa untuk mempresentasikan di depan kelas hal-hal yang berkaitan Narrative tekspenggunaan media flash card, waktu untuk presentasi adalah 3 menit untuk masingmasing kelompok.

e. Guru menindaklanjuti pembelajaran itu dengan menerangkan materi pelajaran tentang hal-hal yang berkaitan dengan Narrative teks menggunakan media interaktif, waktu yang digunakan selama 10 menit.

f. Guru bersama-sama siswa mendemonstrasikan penggunaan media Flash card materi Narrative teks selama 10 menit.

g. Guru bersama-sama siswa melukukan kegiatan vocabulary materi Narrative teks

h. Guru memberikan tugas secara individu selama 15 menit

i. Guru menutup pelajaran dengan mengucapkan salam.

C. Hasil Tindakan Siklus 1

Selama pembelajaran berlangsung dilakukan observasi untuk mengetahui pengaruh kegiatan pembelajaran dalam meningkatkan hasil listening skills siswa dalam proses pembelajaran materi Narrative teks . Pada pembelajaran ini siswa yang masuk sebanyak 32 siswa. Guru mengamati, ternyata pada setiap kelompok masih didapati siswa yang kurang memperhatikan pelajaran yang berkaitan denganNarrative teks, dan masih berbicara dengan teman didekatnya tentang hal-hal yang tidak berkaitan dengan materi pembelajaran. Melalui serangkaian pertanyaan yang disampaikan kepada siswa, sebagian diantaranya belum memahami dan bahkan tidak tau apa yang di diskusikan dalam kelompoknya.

Tabel 2. Hasil Siklus I Hasil Belajar Siswa dalam Siklus 1

\begin{tabular}{llcl}
\hline No & Nama Siswa & Nilai & Predikat \\
\hline 1 & Ainin Alfinyah & 80 & Tuntas \\
2 & Akmad Fatoni Pratama & 70 & Tuntas \\
3 & Akmal Surya & 70 & Tuntas \\
4 & Ali Fauzi & 80 & Tunas \\
5 & Alvin Andriansyah & 60 & Belum Tuntas \\
6 & Ammar Zahir Rizqi & 60 & Belum Tuntas \\
7 & Bella Indri Lestari & 70 & Tuntas \\
8 & Calvin Ananda Dagin & 80 & Tuntas \\
9 & Chindi Kartika Sari & 50 & Belum Tuntas \\
10 & Dwi Arrisa Putri Wibowo & 60 & Belum Tuntas \\
11 & Eka Nurul Wijayanti & 70 & Tuntas \\
12 & Elvina Ujik Aprilia & 70 & Tuntas \\
13 & Farizki Syaiful Marzuki & 90 & Belum Tuntas \\
14 & M. Hendra Firdiansyah & 60 & Belum Tuntas \\
15 & M.Lukmanul Hakim & 75 & Tuntas \\
16 & Marlina & 70 & Tuntas \\
17 & Mochammad Rizal Y & 60 & Belum Tuntas \\
18 & Mohamad Figo Pratama & 80 & Tuntas \\
19 & Mohamad Misbaqul A & 60 & Belum Tuntas \\
20 & Mokhamad Iqbal Firdaus & 90 & Tuntas \\
21 & Muhamad Ali Ali Alazaqi & 80 & Tuntas \\
22 & Muhamad Ari Fudin & 60 & Belum Tuntas \\
23 & Muhamad Rifyal Anwar & 60 & Belum Tuntas \\
\hline
\end{tabular}




\begin{tabular}{llcl}
\hline 24 & Nadia Laili Putri & 80 & Tuntas \\
25 & Nur Diniyanti & 60 & Belum Tuntas \\
26 & Rahayu Wilujeng & 80 & Tuntas \\
27 & Rika Khusnia & 60 & Belum Tuntas \\
28 & Riski Yogi Kurniawan & 70 & Tuntas \\
29 & Roudhotul Ilmi & 80 & Tuntas \\
30 & Siti Kholifah & 70 & Tuntas \\
31 & Vicci Ferdian Aprillio & 80 & Tuntas \\
32 & Zessica Angelia Putri P & 70 & Tuntas \\
& Jumlah & 2460 & \\
& Rata-Rata & 70.28 & \\
\hline
\end{tabular}

Berdasarkan Tabel 2 tersebut dapat dikatakan bahwa kemampuanvocabulary siswa mengalami peningkatan yang cukup signifikan. Pada Siklus I diperoleh rata-rata nilai 71,615 $(<70,00)$. Hasil tersebut menunjukkan bahwa secara umum, siswa belum tuntas.

Berdasarkan Tabel di atas jumlah nilai observasi kegiatan siswa belum memuaskan menurut kategori tingkat keaktifan siswa, berarti dalam mengikuti pelajaran siswa masih kurang aktif, karena anggota kelompok masih terlalu banyak dan siswa belum terbiasa diskusi. Maka pada pertemuan selanjutnya peneliti yang sekaligus sebagai guru menyimpulkan bahwa perlu diadakan siklus selanjutnya. Pada siklus I peneliti akan melanjutkan penerapan media flash cardpada proses pembelajaran Bahasa Inggris

D. Refleksi Tindakan Siklus 1

Dalam pelaksanaan kegiatan belajar mengajar pada siklus I yang masih terdapat kekurangankekurangan, Maka perlu adanya revisi untuk dilakukan pada siklus II antara lain :

a. Guru dalam memotifasi siswa hendaknya dapat membuat siswa lebih termotivasi selama proses belajar mengajar berlangsung.

b. Guru harus lebih dekat dengan siswa sehingga tidak ada perasaan takut dalam diri siswa, sehingga siswa lebih berkosentrasi dalam pembelajaran yang berkenaan dengan vocabulary

c. Guru harus lebih bersabar dalam membimbing siswa berdiskusi untuk menemukan hal-hal baru yang berkaitan dengan materi serta dalam mempraktekkan vocabulary secara estafet.

d. Guru harus mendistribusikan waktu secara baik sehingga kegiatan pembelajaran sesuai dengan yang diharapkan.

Guru sebaiknya menambah lebih banyak contoh soal dan memberi soal-soal latihan pada siswa untuk dikerjakan pada setiap kegiatan vocabulary Paparan Hasil Tindakan Siklus II.

\section{A. Perencanaan Tindakan Siklus II}

Perencanaan di mulai dengan membentuk kelompok diskusi. Siswa yang berjumlah 32 siswa dibagi menjadi 8 kelompok sehingga masing-masing kelompok berjumlah 4 siswa. Materi pelajaran yang diajarkan pada siklus 2 ini tetappada pokok bahasan Narrative teks. Proses pembelajaran pokok bahasan Narrative teks ini menggunakan media flash cardyang diterapkan oleh guru secara langsung dalam pembelajaran di kelas.

a. Pelaksanaan Tindakan Siklus II

Pelaksanaan tindakan siklus II dapat diuraikan sebagai berikut:

1. Guru mengawali pembelajaran dengan mengucapkan salam dan menanyakan jumlah siswa yang hadir.

2. Guru melaksanakan apersepsi.

3. Guru membagi siswa dalam kelompok diskusi, kemudian memberi tugas yang berkaitan dengan penggunaan media flash card .Guru memberi tugas kepada siswa untuk mempresentasikan di depan kelas hal-hal yang berkaitan Narrative teks penggunaan media flash card, waktu untuk presentasi adalah 3 menit untuk masing-masing kelompok.

4. Guru menindaklanjuti pembelajaran itu dengan menerangkan materi pelajaran tentang hal-hal yang berkaitan dengan Narrative teks menggunakan media interaktif, waktu yang digunakan selama 10 menit. 
5. Guru bersama-sama siswa mendemonstrasikan penggunaan mediaflash card materi Narrative teks selama 10 menit.

6. Guru bersama-sama siswa melukukan kegiatan penguasaan Vocabulary materi Narrative teks

7. Guru memberikan tugas secara individu selama 15 menit

8. Guru menutup pelajaran dengan mengucapkan salam.

B. Hasil Tindakan Siklus II

Selama pembelajaran berlangsung dilakukan observasi untuk mengetahui pengaruh kegiatan pembelajaran dalam meningkatkan hasil penguasaan vocabulary siswa dalam proses pembelajaran materi Narrative teks. Pada pembelajaran ini siswa yang masuk sebanyak 32 siswa.Guru mengamati, ternyata setiap kelompok siswa memperhatikan pelajaran yang berkaitan dengan Vocabulary dengan baik, dan tidak lagi berbicara dengan teman didekatnya tentang hal-hal yang tidak berkaitan dengan materi pembelajaran.

Tabel 3. Hasil Siklus II Nilai Tes Formatif Siswa dalam Siklus 2

\begin{tabular}{|c|c|c|c|}
\hline No & Nama Siswa & Nilai & Predikat \\
\hline 1 & Ainin Alfiniyah & 80 & Tuntas \\
\hline 2 & Akhmad Fathoni Pratama & 70 & Tuntas \\
\hline 3 & Akmal Surya & 80 & Tuntas \\
\hline 4 & Ali Fauzi & 90 & Tunas \\
\hline 5 & Alvin Andriansyah & 80 & Tuntas \\
\hline 6 & Ammar Zahir Rizqi & 80 & Tuntas \\
\hline 7 & Bella Indri Lestari & 80 & Tuntas \\
\hline 8 & Calvin Annanda Dagin & 90 & Tuntas \\
\hline 9 & Chindi Kartika Sari & 60 & Belum Tuntas \\
\hline 10 & Dwi Arrisa Putri Wibowo & 90 & Tuntas \\
\hline 11 & Eka Nurul Wijayanti & 80 & Tuntas \\
\hline 12 & Farizki Syaiful Marzuki & 75 & Tuntas \\
\hline 13 & M. Hendra Firdiansyah & 70 & Tuntas \\
\hline 14 & M.Lukman Hakim & 90 & Tuntas \\
\hline 15 & Marlina & 80 & Tuntas \\
\hline 16 & Mochamad Rizal Y & 80 & Tuntas \\
\hline 17 & Mochamad Elsa Septiono & 70 & Tuntas \\
\hline 18 & Mohamad Figo Pratama & 80 & Tuntas \\
\hline 19 & Mohammad Misbaqul A & 90 & Tuntas \\
\hline 20 & Mokhamad Iqbal Firdaus & 80 & Tuntas \\
\hline 21 & Muhhamad Ali Alazaqi & 80 & Tuntas \\
\hline 22 & Muhammad Rifudin & 90 & Tuntas \\
\hline 23 & Muhammad Rifyal Anwar & 60 & Belum Tuntas \\
\hline 24 & Nadia Laila Putri & 90 & Tuntas \\
\hline 25 & Nur Diniyati & 80 & Tuntas \\
\hline 26 & Rahayu Wilujeng & 80 & Tuntas \\
\hline 27 & Rika Khusna & 80 & Tuntas \\
\hline 28 & Riski Yogi Kurniawan & 90 & Tuntas \\
\hline 29 & Roudhotul Ilmi & 90 & Tuntas \\
\hline 30 & Siti Kholifah & 80 & Tuntas \\
\hline 31 & Vicci Ferdian Aprilio & 79 & Tuntas \\
\hline \multirow[t]{3}{*}{32} & Zessica Angelina Putri P & 80 & Tuntas \\
\hline & Jumlah & 2814 & \\
\hline & Rata-Rata & 80.4 & \\
\hline
\end{tabular}

Sumber Data : Hasil Ulangan Harian Siswa

Berdasarkan Tabel 4.3 tersebut dapat dikatakan bahwa kemampuan vocabulary siswa mengalami peningkatan yang cukup signifikan. Pada Siklus II diperoleh rata-rata nilai 80,615 (> 75,00 yang 
merupakan KKM Mapel Bahasa Inggris). Hasil tersebut menunjukkan bahwa secara umum, semua siswa tuntas.

Berdasarkan Tabel di atas jumlah nilai observasi kegiatan siswa memuaskan menurut kategori tingkat keaktifan siswa, berarti dalam mengikuti pelajaran siswa sangat aktif, karena anggota kelompok hanya 4 orang dan siswa sudah terbiasa untuk melakukan kegiatan pembelajaran menggunakan media flash card, sehingga vocabulary siswa semakin meningkat.

\section{Refleksi Tindakan Siklus II}

Dalam pelaksanaan kegiatan belajar mengajar pada siklus II ini masih terdapat kekurangankekurangan. Maka perlu adanya revisi untuk dilakukan pada siklus II antara lain :

a. Guru dalam memotifasi siswa hendaknya dapat membuat siswa lebih termotivasi selama proses belajar mengajar berlangsung.

b. Guru harus lebih dekat dengan siswa sehingga tidak ada perasaan takut dalam diri siswa, sehingga siswa lebih berkosentrasi dalam pembelajaran yang berkenaan dengan vocabulary.

c. Guru harus lebih bersabar dalam membimbing siswa berdiskusi untuk menemukan hal-hal baru yang berkaitan dengan materi serta dalam mempraktekkan vocabulary secara estafet.

d. Guru harus mendistribusikan waktu secara baik sehingga kegiatan pembelajaran sesuai dengan yang diharapkan.

e. Guru sebaiknya menambah lebih banyak contoh soal dan memberi soal-soal latihan pada siswa untuk dikerjakan pada setiap kegiatan vocabulary.

Sebelum perlakuan diberikan pada masing-masing kelompok, nilai rerata pretes siswa sebelum diberi perlakuan pembelajaran dengan media flash cardadalah 69,425.Setelah siswa diberi perlakuan pembelajaran dengan media interaktif pada siklus I mengalami peningkatan menjadi 71,615, namun hasil ini belum memenuhi kriteria ketuntasan minimal hasil belajar siswa mata pelajaran bahasa inggris yaitu 75,00 .

Bila dihitung berdasarkan nilai rerata pretes, kelompok siswa yang diberi perlakuan pembelajaran dengan media flas card setelah dilaksanaknnya siklus ke II mengalami peningkatan rerata hasil belajar sebesar $80,615-69,425=11,19$.

Berdasarkan hasil pada sisklus penelitian tersebut di atas, dapat ditunjukkan bahwa adaperbedaan hasil belajar penguasaan vocabulary antara siswa yang diajar menggunakan metode pembelajaran dengan dibantu media flash card

Hasil ini sesuai dengan teori yangmengatakan bahwa apabila menginginkan siswa berinteraksi denganpembelajaran, maka komputer multimedia adalah pilihan yang paling tepat.Dengan multimedia, siswa dapat belajar sambil bermain, melakukan drilling danlatihan, belajar bagaimana belajar, membuat keputusan, dan bekerjasama. Siswa dapat belajar sesuai dengan materi yang dipelajari diliputi dengan rasa senang.

Multimedia dapat digunakan untuk menyimak lagu, melatih pengucapan, menghafalkan dan mengetahui arti dari lagu tersebut. Pembelajaran vocabulary membutuhkan visualisasi agar supaya siswa lebih mudah melihat pesan apa yangdiinginkan. Konteks apa yang ada dengan latar belakang yang menyertai wacana lisan yang muncul dapat membantu siswa dalam penguasaan vocabulary. Microskills dalam listening seperti misalnya: pengenalan bunyi, memprediksi apa yang akan dikatakan seseorang, memprediksi kata-kata atau frase yang tidak dikenal/diketahui, memahami teks lisan, dan budaya luar perlu visualisasi danagar lebih mudah memahaminya diperlukan media yang interaktif dan dapatmelibatkan paling tidak dua indera dan juga bagian tubuh yang lain misalnya jaridan tangan yang dapat mengoperasikan mouse dan keyboard. Jadi jelaslah bahwamedia pembelajaran yang digunakan guru di kelas dalam penyampaian materipelajaran akan sangat berpengaruh terhadap pencapaian prestasi belajar vocabulary iswa.

Hasil penelitian ini juga didukung oleh hasil penelitian Nugraheni (2012) yang menyatakan bahwa ada perbedaan hasil belajar antara siswa yang diajar dengan media bergambar dan yang diajar dengan media flash card. Siswa yang diajar dengan media audiovisual dan memperoleh rata-rata nilai sebesar 80,115, lebih tinggi daripada siswa yang diajar dengan media lainnya, yaitu 69,425

Dale dalam Arsyad (2011) mengemukakan bahwa media pembelajaran flash card memberikan banyak manfaat diantaranya membawa kesegaran dan variasi belajar bagi siswa, membuat hasil belajar lebih bermakna bagi berbagai kemampuan siswa dan mendorong pemanfaatan yang bermakna dari mata pelajaran dengan melibatkan imajinasi dan partisipasi aktif yang mengakibatkan meningkatkan hasil belajar siswa. Disamping itu melalui media audiovisual/video dapat menyajikan informasi, 
memaparkanproses, menjelaskan konsep-konsep yang rumit, mengajarkan ketrampilan, menyingkat atau memperpanjang waktu dan mempengaruhi sikap siswa.

Penggunaan media visual juga dapat memperlancar pemahaman terhadapsesuatu dan memperkuat ingatan. Melalui media visual dapat menumbuhkan minat siswa dan memberikan hubungan antara isi materi pembelajaran dengan dunia nyata.Namun, agar menjadi lebih efektif, media flash card perlu ditempatkan pada konteksyang bermakna dan siswa harus berinteraksi dengan visual itu untuk meyakinkanterjadinya proses informasi.

Senada dengan hasil penelitian di atas, Ariputri \& Supraptono (2015) dalam penelitiannya yang berjudul "Penggunaan Media Pembelajaran Flash Carddengan Menggunakan Aplikasi "Smarty Way" Berbasis Android" menyimpulkan bahwa ada perbedaan hasil belajar English vocabulary sebelum dan sesudah perlakuan. Sebelum perlakuan, siswa diajar menggunakan metode ceramah dibantuinteraktif berbasis Android sebesar memperoleh skor rata-rata hasil belajar English Vocabulary sebesar 80,115.

Penerapan pembelajaran dengan mediaflash cardmemberikan pengaruh yang lebih baik pada perolehan hasil belajar Penguasaan Vocabulary daripada penerapan pembelajaran dengan media lainya. Dengan kata lain dapat diinterpretasikan bahwa penerapan pembelajaran dengan dibantu mediaflash card lebih efektif dalam perolehan hasil belajar vocabulary daripada pembelajaran dengan lainnya.

\section{Simpulan Dan Saran}

Berdasarkan hasil penelitian dan pembahasan yang telah dipaparkan pada bab sebelumnya, maka dapat ditarik kesimpulan sebagai berikut:

Penggunaan media pembelajaran flash card dapat meningkatkan penguasaan vocabulary dengan materi narrative teks di kelas XI RPL2 SMKN 1 Dlanggu. Nilai rerata hasil belajar penguasaan vicabulary siswa setelah mendapat pembelajaran dengan media flash cardsebesar 80,115 lebih tinggi daripada sebelum siswa yang mendapat perlakuan pembelajaran dengan media flash cardyaitu 69,425, artinya setelah adanya perlakuan pembelajaran menggunakan media flash cardterdapat kenaikan perolehan hasil belajar siswa sebesar 11,19. Hal ini dapat diartikan bahwa secara individu, pembelajaran dengan media flash card memiliki pengaruh yang signifikan terhadap hasil belajar penguasaan vocabulary

Berdasarkan temuan dan refleksi penerapan pembelajaran dengan media flash card terhadap penguasaan vocabulary||siswa kelas XI SMKN 1 Dlanggu, maka beberapa saran yang dapat diajukan adalah: 1) Para guru dalam pembelajaran hendaknya menggunakan media flash card, khususnya pembelajaran bahasa Inggris pada materi atau pokok bahasan tertentu, sesuai dengan karakteristik pembelajaran, 2) Sebelum melaksanakan pembelajaran hendaknya guru mempersiapkan terlebih dahulu bahan dan alat pembelajaran demi kelancaran kegiatan, dan 3) Sebelum melakukan pembelajaran di kelas, Guru mampu melakukan setting kelas sesuai rencana.

\section{Daftar Rujukan}

Arsyad, A. (2007).Media Pembelajaran.Jakarta:Raja GrafindoPersada

Dananjaya, U. (2010). Media Pembelajaran Aktif.Bandung:Nuansa

Iskandarwassid dan Sunendar, D.(2008). Strategi Pembelajaran Bahasa. Bandung:PT Remaja Rosdakarya

Izzan, A. (2008). Metodologi pembelajaran Bahasa Inggris. Bandung: Humaniora.

Izzan, A. (2009). Metodologi pembelajaran Bahasa Arab. Bandung:Humaniora.

Kusumawati, Rita. 2016. Pengembangan Media Flashcard Tema Binatang Untuk Anak Kelompok B Di Taman Kanak-Kanak Asemjajar-Surabaya . Jurnal Teknologi Pendidikan, Vol.4 No.1, April 2016

Mulyasa.(2008). Penelitian Tindakan Kelas.Jakarta:PT Remaja Rosdakarya.

Mukarto.(2007).Grow With English.Jakarta :Erlangga

Maghfiroh, Lailatul. (2013). Penggunaan Media Flashcard Untuk Meningkatkan Hasil Belajar Ips Pada Pembelajaran Tematik Di Sekolah Dasar . JPGSD Volume 01 Nomor 02 Tahun 2013 
Permadi,D.danSuryana,N.(2000). Pendekatan, Metode, Tehnikdan Mode IPembelajaran Bahasa Inggris di $S D$ dan MI. Bandung:Sarana Panca Karya

Purwanto, N. (2006). Evaluasi Pengajaran. Bandung:PT Remaja

Rosdakarya. Sugiono. (2010). Statistika untuk Penelitian. Bandung:Alfabeta.

Susilana,R. dan Riyana,C.(2009). Media pembelajaran. Bandung:CVWacana Prima.

Tarigan, H (2018) Menyimak sebagai suatu ketrampilan berbahasa, Bandung : Angkasa.

Tarigan,H (2018), Berbicara sebagai suatau keterampilan berbahasa. Bandung : Angkasa 